\title{
BEYOND THE SECTARIAN DIVIDE: \\ THE "VOICE OF THE TEACHER" AS AN AUTHORITY-CONFERRING STRATEGY IN SOME QUMRAN TEXTS
}

\author{
Florentino García Martínez
}

For John J. Collins, a friend of many years and a true "Teacher" from whom I have learned so much.

\section{Putting the Paper in Context}

The biggest difference in the approach to the collection of manuscripts from the caves around Qumran between now and twenty years ago is that now we can consider the collection as a whole. ${ }^{1}$ Of course, our view of the collection is totally partial and accidental since we cannot even fathom what the collection as a whole was like at the moment it was deposited in the caves. The stories of previous discoveries (in the times of Origen, ${ }^{2}$ of the Patriarch Timotheus $I^{3}{ }^{3}$ the Karaites, ${ }^{4}$ etc.), as well as the enormous amount of "jarres à manuscrits" found in the caves, ${ }^{5}$ whole or broken, is a caveat we should never forget and which makes all our speculations tentative. ${ }^{6}$ Nevertheless, we can now

1 This is a well known truism whose consequences I have tried to explore in Florentino García Martínez, "Qumrân, 60 ans après la découverte," The Qumran Chronicle 15 (2007): 111-138.

2 As reported by Eusebius, Ecclesiastical History 6:16:1.

${ }^{3}$ In his letter to Mar Sergius, metropolitan of Elam, edited by O. Braun in Oriens christianus 1 (1901): 299-313; see Paul Kahle, Die hebräischen Handschriften aus der Höhle (Stuttgart: W. Kohlhammer, 1951), 56-61.

${ }^{4}$ For a summary of the evidence, see the article by Fred Astren, "Karaites," in Encyclopedia of the Dead Sea Scrolls (ed. L. H. Schiffman and J. C. VanderKam; Oxford: New York, 2000), 1:462-465 and the bibliography there.

${ }^{5}$ According to Roland de Vaux, more than fifty in Cave 1 (DJD 1:8), and a total of 106 in the caves of the cliff (DJD 3:14), of which 35 in Cave 3 (DJD 3:8).

${ }^{6}$ De Vaux, DJD 3:34, after referring to the reported discovery alluded to in the letter of Patriarch Timotheus, comments: "La grotte de Thimotée peut être l'une de celles où des fragments ont encore été découverts récemment; elle peut être aussi l'une de celles où nous avons recueillie de la poterie mais pas d'écrits, si l'on suppose que les Juifs venus de Jérusalem ont emporté tous les manuscrits qui s'y trouvaient. On peut songer particulièrement à la grotte $\mathrm{n}^{\circ} 29$, cette chambre ronde où l'on accède par un 
consider the remains that have come to us as a whole, and this view is not without consequences. ${ }^{7}$

The collection as a whole appears to me (with the exception of a few documentary texts of uncertain provenance $)^{8}$ as formed by religious texts (in Hebrew, in Aramaic and a few in Greek) ${ }^{9}$ whose formation has been influenced by other religious texts (Scripture) considered more or less authoritative by the collectors. The same authority-conferring strategies we can discern in these authoritative texts are used in all other religious texts of the collection.

The pluriformity of the so-called "biblical texts" and the fact that this pluriformity was perceived not as a problem, but as opportunity for interpretation, has led scholars who deal with the so-called "biblical texts" from the collection to realize that in the historical context of the collection, we are clearly at the other side of the "Great Divide" of which Talmon speaks, ${ }^{10}$ and that, therefore, speaking of "Bible" is a complete anachronism. ${ }^{11}$ In the collection we do find scrolls, many scrolls, which later will become "biblical books" (Scripture) in many different forms, be it in clearly different textual forms (short, long, revised, reworked, abstracted, versions) or different editions, or rewritten in the form of new compositions, and all of them used

étroit tunnel. On y a retrouvé les éléments d'une douzaine de jarres et dix-sept couvercles dont sept étaient intacts et empilés contre la paroi, à part des jarres. Cette disposition pourrait être l'indice d'une violation ancienne: les jarres auraient été vidées, et elles contenaient peut-être des manuscrits, comme celles de la grotte 1Q. Mais ces conjectures sont assez vaines." Hartmut Stegemann links the reported discovery of the letter of Timotheus to the alleged discovery by the Karaites, and thinks that the data perfectly fit Cave 3, which may have contained between 70 and 140 scrolls; see his The Library of Qumran (Grand Rapids: Eerdmans and Leiden: Brill, 1998), 68-71.

7 As I have tried to show by "revisiting" Cave 1 and Cave 11 within this perspective in two forthcoming publications, "Reconsidering the Cave 1 Texts Sixty Years After Their Discovery: An Overview," in IOQS Meeting, Lubljana (ed. E. J. C. Tigchelaar et al.; STDJ; Leiden: Brill, forthcoming) and "Cave 11 in Context," in The Landscape of the Dead Sea Scrolls (ed. C. Hempel; STDJ; Leiden: Brill, forthcoming).

${ }^{8}$ See the list in Armin Lange and Ulrike Mittmann-Richert, "Annotated List of the Texts from the Judaean Desert Classified by Content and Genre," in DJD 39:143-144.

${ }^{9}$ Emanuel Tov, Revised Lists of the Texts from the Judaean Desert (Leiden: Brill, 2010) gives a complete overview.

${ }_{10}$ Shemaryahu Talmon, "The Crystallization of the 'Canon of Hebrew Scriptures' in the Light of Biblical Scrolls from Qumran," in The Bible as Book: The Hebrew Bible and the Judaean Desert Discoveries (ed. E. D. Herbert and E. Tov; London: The British Library and New Castle: Oak Knoll, 2000), 5-20, 14.

${ }^{11}$ This also is nowadays a well-known truism. See, most recently, Florentino García Martínez, "Rethinking the Bible: Sixty Years of Dead Sea Scrolls Research and Beyond," in Authoritative Scriptures in Ancient Judaism (ed. M. Popović; JSJS; Leiden: Brill, forthcoming). 
indiscriminately. ${ }^{12}$ We also find indications that two groups of books, designated as "Moses" (or the Torah) and the "Prophets" were already considered different from and more authoritative than the others, although we do not know for sure which books were included in these two groups, particularly in the group of the "Prophets." Their authority is evident from the way they are used, quoted, interpreted or rewritten in other compositions. ${ }^{13}$ However, these authoritative texts were not identical with, nor limited to, those which we will later find in the Jewish or Christian Bible, since we find the same authoritative strategies (like recourse to the divine voice, rewriting and/or interpretation) used with many of them (like Jubilees, Aramaic Levi, Temple Scroll or Apocryphon of Joshua, to quote the most obvious).

And something similar happened, it seems to me, with the so-called "sectarian" texts. Even those core texts which have revealed particular groups to us (the yahad group or the mahanot groups) are in multiple forms. And nowadays, when all the evidence has been published, they are understood in a completely different way from the way they were understood twenty years ago, since they show us a web of relationships among those groups, groups certainly interconnected, but in no way identical. $^{14}$

All this has resulted in a taxonomic impasse, both for the so-called "biblical" scrolls and for the other compositions. ${ }^{15}$ Scholars dealing with the so-called "biblical" scrolls found in the collection have tried to avoid this impasse by paying attention to the "authoritativeness" of the compositions within the collection as a whole. And I have suggested that we can also come out of the impasse of the so-called "non-biblical scrolls" of the collection by paying more attention to the authorityconferring strategies used in them, since these are the same as are used to show the authority of the so-called "biblical" scrolls; and when we consider the collection as a whole, in a truly historical perspective, all we found there are religious texts whose origins in most cases

${ }^{12}$ See the different studies by Eugene Ulrich, particularly those included in his The Dead Sea Scrolls and the Origins of the Bible (SDSSRL; Grand Rapids: Eerdmans and Leiden: Brill, 1999), 3-120.

${ }^{13}$ See Florentino García Martínez, "I testi qumranici testimoni di scritture autorevoli," in Convegno di Studi Veterotestamentari, Ariccia 2009 (ed. G. Prato; Bologna: Dehoniane, forthcoming).

${ }^{14}$ For an excellent summary, see John J. Collins, Beyond the Qumran Community: The Sectarian Movement of the Dead Sea Scrolls (Grand Rapids: Eerdmans, 2010).

${ }^{15}$ Florentino García Martínez, “¿Sectario, no-sectario o qué? Problemas de una taxonomía correcta de los textos qumránicos," RevQ 23/91 (2008): 383-394. 
cannot be determined, but whose formation has been influenced by other precedent religious texts considered more or less authoritative. ${ }^{16}$ And it seems to me that the same authority-conferring strategies are used in all the texts of the collection, including the so-called "sectarian" texts.

This explains the first part of the title of my paper: "Beyond the Sectarian Divide." The second part of this title tries to focus on one of the strategies used by the compositions authored by the groups that put together the collection (the core "sectarian" texts: Damascus Document, Serek, Hodayot, Pesharim, Milhamah) in order to invest their own compositions with the same authoritative status of the other compositions their authors clearly recognized as authoritative ("Moses" and "the Prophets," but also compositions like Jubilees, Temple Scroll, Apocryphon of Joshua, Aramaic Levi). I have called this strategy "the Voice of the Teacher," an expression used twice in the Damascus Document (CD 20:28.32).

\section{The Voice of the Teacher}

On CD 20:27-34 we can read: ${ }^{17}$

$27 \ldots$ But all those who remain steadfast in these regulations, [co]ming 28 and going in accordance with the law, and listen to the Teacher's voice,

${ }^{16}$ This is also true for the Aramaic texts, which form a sizeable minority of the collection (about 120 manuscripts, of which about eighty, belonging to twenty-nine compositions, preserve enough text to be treated in a meaningful way); see Florentino García Martínez, "Scribal Practices in the Aramaic Literary Texts from Qumran," in Myths, Martyrs, and Modernity: Studies in the History of Religions in Honour of Jan N. Bremmer (ed. J. Dikstra, J, Kroesen, Y. Kuiper; Numen Book Series 127; Leiden: Brill, 2010), 329-341.

${ }^{17}$ For the Cairo Geniza text, see the editions by S. Schechter, Fragments of a Zadokite Work (Documents of Jewish Sectaries 1; Cambridge: CUP, 1910); Chaim Rabin, The Zadokite Documents (2d. rev. ed.; Oxford: Clarendon, 1958); Eduard Lohse, Die Texte aus Qumran: Hebräisch und Deutsch (München: Kösel, 1971); Elisha Qimron, in The Damascus Document Reconsidered (ed. M. Broshi; Jerusalem: Israel Exploration Society, 1992); Florentino García Martínez and Eibert J. C. Tigchelaar, The Dead Sea Scrolls Study Edition (Leiden: Brill and Grand Rapids: Eerdmans, 2000), vol. 1 (= DSSSE 1), and Joseph M. Baumgarten and Daniel R. Schwartz, "The Damascus Document," in The Dead Sea Scrolls: Hebrew, Aramaic, and Greek Texts with English Translations (ed. J. H. Charlesworth; The Princeton Theological Seminary Dead Sea Scrolls Project; Tübingen-Louisville: Mohr-Westminster John Knox, 1995), vol. 2. For the Cave 4 copies, see Joseph M. Baumgarten, DJD 18. For a reconstruction of the composite document, using the Geniza copies and those from Qumran, see Ben Zion Wacholder, The New Damascus Document (STDJ 56; Leiden: Brill, 2007). 
and confess before God: "Assuredly 29 have we sinned, both we and our fathers, walking contrary to the ordinances of the covenant; just[ice] 30 and truth are your judgments against us"; and they do not raise their hand against his holy regulations and his just 31 judgment[s] and his truthful stipulations; and they are instructed in the first ordinances, 32 in conformity with which the men of the Unique One were judged; and they lend their ears to the voice of the Teacher of Righteousness; and do not reject 33 the just regulations when they hear them; these shall exalt and rejoice and their heart will be strong, and they shall prevail 34 over the sons of the world. And God will atone for them, and they shall see his salvation, for they have taken refuge in his holy name. ${ }^{18}$

This sentence, with a very long protasis (in which the "voice of the Teacher" appears twice, the first time as קול מורה, the second time as (קול מורה צדק) and a short apodosis, is the concluding section of the "Admonition" on CD-B which is followed by a few more lines in 4Q266 4 7-13 (if the placement of this fragment by Milik and Baumgarten is correct). ${ }^{19}$ The sentence is generally considered (by scholars as different as Philip Davies ${ }^{20}$ or Stephen Hultgren ${ }^{21}$ ) to represent a reworking of the original text of $\mathrm{CD}$ within what they call "a Qumran recension." They based themselves on the force of the reference to the "first (or former) ordinances" (20:31) and, in the case of Davies, ${ }^{22}$ on the understanding of אנשי היחיד (20:32, which we have translated as "men of the Unique One") as אנשי היחד, "the men of the community" (an understanding which is widely shared among scholars, for example Rabin, Lohse, Qimron and Baumgarten, among the editors of the text of the Damascus Document). Without elaborating here on the complicated matter of the relationship of the Damascus Document and the Serek, and consequently on the development and relationship of the communities for which these documents legislate, ${ }^{23}$ I think we can

18 Translation according to DSSSE 1:581.

19 Baumgarten on DJD 18:47. These fragments would have formed column $\mathrm{X}$ in Stegemann's reconstruction; see Hartmut Stegemann, "Towards a Physical Reconstruction of the Qumran Damascus Document Scrolls," in The Damascus Documents: A Centenial of Discovery (ed. J. Baumgarten, E. G. Chazon, and A. Pinnick; STDJ 34; Leiden: Brill, 2000), 177-200, 180.

20 Philip R. Davies, The Damascus Covenant: An Interpretation of the "Damascus Document" (JSOTSS 25; Sheffield: JSOT Press, 1982), 173-197.

${ }^{21}$ Stephen Hultgren, From the Damascus Covenant to the Covenant of the Community (STDJ 66; Leiden: Brill, 2007), 67-73.

22 Davies, The Damascus Covenant, 197.

${ }^{23}$ For a good summary of the discussions, see Charlotte Hempel, "Community Structures in the Dead Sea Scrolls: Admission, Organization, Disciplinary Procedures," in The Dead Sea Scrolls After Fifty Years: A Comprehensive Assessment (ed. P. W. Flint 
use "the voice of the Teacher" as a shorthand indication for all the core "sectarian" documents to which I refer (Damascus Document, Serek, Hodayot, Pesharim, Milhamah), independently of the appearance or not in these documents of the figure of the Teacher (who appears in CD 20:29 and in the pesharim, but is not mentioned explicitly in the other core documents).

Of course, reading מששי היחד here, and מורה היחד in lines 1 and 14 of the same column 20, instead of the מורה היחדיד of the manuscript, will dispel all doubts about the inner relationship of all the core documents. But I do not think this reading is needed. The strong parallelism between the confession here in CD 20:29 "Assuredly have we sinned, both we and our fathers, walking contrary to the ordinances of the covenant; just[ice] and truth are your judgments against us," and the confession at the beginning of the Serek: "And all those who enter the Covenant shall confess after them and shall say: 'We have acted sinfully, we have transgressed, we have sinned, we have acted irreverently, we and our father before us, inasmuch as we walk [in the opposite direction to the precepts] of truth and justice [...] his judgment upon us and upon our fathers'" (1QS 1:24-26) assure us of this relationship. This confession has, of course, strong biblical precedents, like the cry in $1 \mathrm{Kgs}$ 8:47 and the prayers in Daniel 9 or Ps 106:6, and may be related to 4 QDibrey Hame'orot, as Davies observes; ${ }^{24}$ but the parallel with the Serek text is too close to be overlooked, and it strongly suggests a literary relationship between the two documents. Thus, I do not think it is necessary to change the clear reading of the manuscript. Besides, the אנשי היחיד can perfectly well refer to the יחיד היחיד mentioned in CD 20:1 (יורה היחיד on CD 20:14), this figure of the past who was all-important for the different groups.

In my opinion, what this text clearly teaches us is that for the members of the group, listening to the "voice of Teacher" is as fundamental as "coming and going in accordance with the law (על פי התורה)" (which obviously refers to the Torah) (20:27), and that it is the "voice of the Teacher" that lends authority to the חקי הצדק "the just regula-

and J. C. VanderKam; Leiden: Brill, 1999) 2:67-92; Sarianna Metso, "Qumran Community Structure and Terminology as Theological Statement," RevQ 20/79 (2002): 429-444; Hultgren, From the Damascus Covenant to the Covenant of the Community; Alison Schofield, From Qumran to the Yahad: A New Paradigm of Textual Development for The Community Rule (STDJ 77; Leiden: Brill, 2009); and most recently Collins, Beyond the Qumran Community, 66-75.

${ }^{24}$ Davies, The Damascus Covenant, 196. 
tions": "and they lend their ears to the voice of the Teacher of Righteousness, and do not reject the just regulations when they hear them" (20:32-33). It also teaches us that fidelity to both sets of norms (the Torah and their own ordinances) is what will bring final salvation. "The Torah" (התורה) and "the just regulations" (חקי הצדק) are clearly different matters, but both are equally authoritative. The strict parallel between the two shows us, it seems to me, that the "voice of the Teacher" is used as a strategy to give authority to the norms of the group, in a similar way as the "voice of Moses" is used in 4Q266 1a-b 15-16 ("and do not listen] to the voice of Moses") ${ }^{25}$ or in 4Q378 $263^{26}$ "they pa[y]ed attention to the voice of Mo[ses...]" to express the authority of the revealed Torah.

In spite of the many proposals, we cannot put a personal name to the figure of the Teacher mentioned in the Scrolls. ${ }^{27}$ Neither can we pinpoint exactly the time of his actuation. ${ }^{28}$ We know for sure that the historical Teacher was a priest ("Its interpretation concerns the Priest, the Teacher of Righteousness" 4Q171 1 iii-iv 15), ${ }^{29}$ and we know that he had a fundamental function in the forming of the group of the Damascus Document: "And God appraised their deeds, because they sought him with an undivided heart, and raised up for them a Teacher of Righteousness, in order to direct them in the path of his heart" (CD 1:10-11). We know that he was called by many names by his followers. The text quoted from CD 20 already uses two: Teacher and Teacher of Righteousness, and (if we follow the reading of the manuscript) a third name, מורה היחיד, "Unique Teacher," is used on the same column in line 14. Based on his confrontations with his enemies, the Wicked Priest and the Man of Lies, we can also conclude that some other names used in the manuscripts refer to the same historical figure. Thus on 4Q171 $1 \mathrm{i} 19^{30}$ he is called מליץ דעת "Interpreter of Knowledge": "Its [interpretation] concerns the Man of Lies who misdirected many with deceptive words, for they have chosen worthless

\footnotetext{
${ }^{25}$ DJD 18:31.

${ }^{26}$ DJD 22:261.

${ }^{27}$ Ranging from Onias III to James the Brother of Jesus, if we remain in the accepted timeframe.

${ }^{28}$ For a review of the proposals, see Michael O. Wise, "Dating the Teacher of Righteousness and the Floruit of his Movement," JBL 122 (2003): 53-87, who advocates a first century B.C.E. dating.

${ }^{29}$ DJD 5:44.

${ }^{30}$ DJD 5:43.
} 
things and did not listen to the Interpreter of Knowledge," an expression we find also in one of the so-called "Hymns of the Teacher" $\left(1 \mathrm{QH}^{\mathrm{a}} 10: 15\right)^{31}$ where it is said: "You have made me a banner for the elect of righteousness and an expert interpreter of wonderful mysteries (ומליץ דעת ברזי פלא)." Even more important is the use in some cases of the name "Interpreter of the Torah" (דורש התורה) to designate the historical Teacher. That is the case in the famous "well midrash" on CD 6:7, where the "Interpreter of the Law" is clearly a figure of the past, as are the "converts of Israel," as opposed to another figure clearly expected in the future who carries a very similar name: "until there arises the one who teaches justice at the end of days" (CD 6:11). The expression used here, יורה הצדק, is a clear allusion to the Teacher title, but the figure so designated is clearly placed in the eschatological future. In other texts, it is the Interpreter who is placed in the eschatological future. Thus, in 4Q174 1-2 i 11-12,32 2 Sam 7:12-14 is thus interpreted: "This refers to the 'branch of David' who will arise with the Interpreter of the Law who will rise up in Zion in the last days." "Branch of David" is one of the designations of the awaited Davidic messiah in the Scrolls. And the Interpreter of the Law will arise with him, evidently in the future. Both titles can thus refer to persons of the past and of the future, and both seem to refer to the same person of the past and the same figure expected in the eschatological future. John Collins has most aptly and succinctly summarized the situation: "This usage suggests that such titles as Interpreter of the Law and Teacher of Righteousness could be variously used to refer to figures past or future, and that they are interchangeable." 33

This multiplicity of referents and their interchangeability should not surprise us, since the activity of "interpreting the law" is one of the basic characteristic of all the yahad groups, as we can read in 1QS 6:6-7:

And in the place where the Ten assemble there should not be missing a man to interpret the law (איש דורש התורה) day and night, always, one relieving another. And the Many shall be on watch together for a third of each night of the year in order to read the book, explain the regulation, and bless together (לקרוא בספר ולדרוש משפט ולברך ביחד).

\footnotetext{
${ }^{31}$ DJD 40:132.

${ }^{32}$ DJD 5:53.

${ }^{33}$ John J. Collins, The Scepter and the Star: the Messiahs of the Dead Sea Scrolls and Other Ancient Literature (New York: Doubleday, 1995), 104.
} 
This clearly points to the fact that the activity of interpreting the law, which is the point of departure of the name given both to the historical "Interpreter of the Law," who is identical to the historical Teacher, and to the expected eschatological "Interpreter of the Law," who is a messianic figure of the future, is a constant function within the groups that gathered the manuscripts. ${ }^{34}$

This allows us to conclude that the "voice of the Teacher" as an authority-conferring strategy is not limited to the activity of the historical Teacher of Righteousness, the one who represented it eminently, but that it was "institutionalized" within the groups that took their inspiration from this figure and became the channel of a continuous revelation while expecting the final revelation at the end of times. This continuous revelation is of an exegetical nature and concerns both the Law and the Prophets, the two aspects we have been considering up to now.

\section{The Teacher as Interpreter of the Law}

As Interpreter of the Law, the "voice of the Teacher" is associated with revealing the hidden aspects of the Torah, the secrets of the divine Law which are not accessible to all Israel, but are only revealed to the members of the group. This understanding is expressed with the categories of nistar (hidden) and nigleh (revealed), which are based on the texts of Deut 29:28, but that in the core sectarian scrolls acquire a new meaning, since what is hidden from Israel is revealed to them. ${ }^{35}$ As CD 3:12-14 puts it: "But with those who remained steadfast in God's precepts, with those who were left from among them, God established his covenant with Israel forever, revealing to them hidden matters

${ }^{34}$ We do not need to go here into the disputed question of the identity of these two figures; see, among others, Jerome Murphy-O'Connor, "The Damascus Document Revisited," RB 92 (1985): 223-246 and Philip R. Davies, "The Teacher of Righteousness and the 'End of Days'," RevQ 13 (1988): 313-317, for the view that the historical Teacher was identified with "the one who shall teach righteousness at the End of Days," and Michael A. Knibb, "The Teacher of Righteousness-A Messianic Title?" in A Tribute to Geza Vermes: Essays in Jewish and Christian Literature and History (ed. P. R. Davies and R. T. White; JSOTSup 100; Sheffield: JSOT Press, 1990), 51-65, and Collins, The Scepter and the Star, 102-123, for a distinction between the two figures.

${ }^{35}$ See the classic explanation of the terms by Lawrence H. Schiffman, The Halakhah at Qumran (SJLA 16; Leiden: Brill, 1975), 22-32, or the more recent by Aharon Shemesh and Chana Werman, "Hidden Things and their Revelation," RevQ 18/71 (1998): 409-427. 
(לגלות להם נסתרות) in which all Israel had gone astray." The activity of the Interpreter is to discover these matters which are hidden from Israel and to disclose them to the faithful: "And every matter hidden from Israel but which has been found out by the Interpreter, he should not keep hidden from them for fear of a spirit of desertion," we read in 1QS 8:11-12. And a little further in the same column (on 1QS 8:15-16) it is made clear that the way the Interpreter is able to find this secret meaning is no other than study: "This is the study of the law which He commanded through the hand of Moses, in order to act in compliance with all that has been revealed from age to age, and according to what the prophets have revealed through his holy spirit." Exegesis is thus a way to revelation; or if we want to formulate it differently: divine revelation, produced by God's spirit, is now continuously accessible through exegesis which, within the group, reveals the true meaning of Torah for each age.

After analyzing the biblical precedents of the concept of "revelatory exegesis" in his book Mediating the Divine, Alex Jassen concludes that in Chronicles and in Ezra "revelation is reconfigured as a process of reading, interpreting, and rewriting ancient prophetic Scripture."36 This process, clearly started within what we call Scripture, is amply developed in later periods. As Collins has indicated: "It is a commonplace that the interpretation of older Scriptures is a major factor in the composition of Jewish writings of the Hellenistic and Roman periods." ${ }^{37}$ Collins proves his point by an analysis of the interpretation of Jeremiah's prophecy of the seventy years in Daniel $9,{ }^{38}$ and concludes: "The fact that that duration is interpreted allegorically, however, and, at least by modern reckoning, corresponds only loosely and schematically to the period identified in the interpretation, suggests that the prediction is not really derived from the prophecy but that the prophecy is invoked to lend authority to a prediction that is made for other reasons." ${ }^{39}$ Daniel's recourse to Jeremiah's prophecy and its interpretation through revelatory exegesis is thus used as an authority-

\footnotetext{
${ }^{36}$ Alex Jassen, Mediating the Divine: Prophecy and Revelation in the Dead Sea Scrolls and Second Temple Judaism (STDJ 68; Leiden: Brill, 2007), 211.

${ }^{37}$ John J. Collins, "Prophecy and Fulfillment in the Qumran Scrolls," in Seers, Sybils and Sages in Hellenistic Judaism (JSJSup 54; Leiden: Brill, 1997), 301.

${ }^{38}$ See John J. Collins, Daniel: a Commentary on the Book of Daniel (Hermeneia; Minneapolis: Fortress, 1993), 344-360.

39 Collins, "Prophecy and Fulfillment," 307 (emphasis FGM).
} 
conferring strategy. And in the collection of manuscript from Qumran, this authority-conferring strategy is employed not only in many of the compositions which interpret prophetic writings, but is also applied to Torah.

In CD 7:14-19 the words of Amos 5:26-27 are interpreted this way:

14 As he said: (Am 5:26-27) "I will deport the Sikkut of your King 15 and the Kiyyun of your images away from my tent to Damascus." Blank The Books of the Law are the Sukkat 16 of the King, as he said (Am 9:11) "I will lift up the fallen Sukkat of David". Blank The King 17 is the assembly. And the Kiyyune of the images <and the Kiyyun of the images $>$ are the books of the Prophets, 18 whose words Israel despised. Blank And the star is the Interpreter of the Law, 19 who will come to Damascus. ${ }^{40}$

You will surely have noticed that the quoted text has only two elements (כיון Dלות, whatever these terms may mean in the biblical

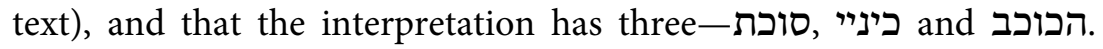
However, if we look at the MT of Amos we find the three terms of the interpretation present because the complete quotation after "and the kiyyun of your images" (ואת כיון צלמיכם) also has "the star of your God" (כוכב אלהיכם). Also in the LXX, which has a somewhat different text that agrees with some elements of the interpretation, the

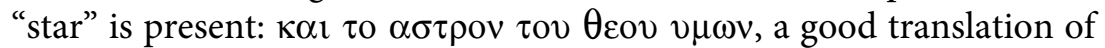
the Hebrew כוכב אלהיכם, which allows us to conclude that "the star" was also in the original quote and has been lost by accident in the medieval copy.

This "Amos Midrash" has been much studied, ${ }^{41}$ but what interests me here is the mention of the "Books of the Torah" (7:15) (ספרי) (ספרי) (התורה), of the "Books of the Prophets" (7:17) (ספרי הנביאים) and, in a strict parallel, the interpretation of the third element, "the star," as "the Interpreter of the Torah" (7:18) (והכוכב הוא דורש התורה). Whether or not the plural expression "the Books of the Torah" is identical to the expression "Book of Moses" (ספר מושה) of 4QMMT"2 as a reference to the Pentateuch is unimportant to me here. ${ }^{43}$ What is important is that

\footnotetext{
${ }^{40}$ In the translation of DSSSE 1:561.

${ }^{41}$ The most important studies are collected in note 66 of Hultgren, From the Damascus Covenant to the Covenant of the Community, 30.

42 4Q397 14-21 10, line C 10 of the composite text, DJD 10:59.

${ }^{43}$ For Wacholder, it would refer to the Pentateuch and the Book of Jubilees; see The New Damascus Document, 239.
} 
it constitutes a group of authoritative writings and is acknowledged as such. Equally, the precise contours of the collection designated "Books of the Prophets" is also less important to me now than its authoritative status, clearly reflected in the fact that "Israel" did not follow its words. However, the really surprising element in this quote is the third one, since "the star" is not interpreted as referring to a group of writings, as we would expect, but as alluding to a person and to his function: the Interpreter, the person who realizes this exegetical activity, and the object of his interpretation is the Torah. The figure who has this function within the group, the "Interpreter of the Torah," is thus placed here strictly in parallel with the two other collections of authoritative writings. ${ }^{44}$ This means, at least to me, that the process of exegesis-the interpretation of the Torah which this figure represents and exercises-and the results of this interpretation are considered as authoritative within the group as the two other groups of writings.

It seems to me highly relevant that in the quoted text of the Serek (1QS 8:11), what the Interpreter finds with his exegesis is precisely "every matter hidden from Israel.” What has been hidden from Israel is precisely those aspects of the Law of Moses that have been revealed to the members of the group, as it is explicitly said in 1QS 5:7-10:

7 Whoever enters the council of the Community 8 enters the covenant of God in the presence of all who freely volunteer. He shall swear with a binding oath to revert to the Law of Moses, according to all that he commanded, with whole 9 heart and whole soul, in compliance with all that has been revealed of it (לכול הנגלה ממנה) to the sons of Zadok, [or "to the council of the men of the community" according to the versions from Cave 4,4Q266 and 4Q268 ${ }^{45}$ the priests who keep the covenant and interpret his will and to the multitude of the men of their covenant

${ }^{44}$ On the authoritative status of the Law and the Prophets in the collection, see, among others, James C. VanderKam, "Authoritative Literature in the Dead Sea Scrolls," DSD 5 (1998): 382-402; Armin Lange, "The Status of the Biblical Texts in the Qumran Corpus and the Canonical Process," The Bible as Book, 21-30; Katell Berthelot, "Les titres des livres bibliques: le témoignage de la bibliothèque de Qumrân," in Flores Florentino: Dead Sea Scrolls and Other Early Jewish Studies in Honour of Florentino García Martínez (ed. A. Hilhorst, E. Puech, and E. J. C. Tigchelaar; JSJS122; Leiden: Brill, 2007), 127-140, and most recently Florentino García Martínez, "I testi qumranici testimoni di scritture autorevoli."

${ }^{45}$ On the much discussed difference between $1 \mathrm{QS}$ and 4QS here, see, most recently Charlotte Hempel, "Do the Scrolls Suggest Rivalry Between the Sons of Aaron and the Sons of Zadok and If So Was It Mutual?" RevQ 24/93 (2009): 135-153 (148-150), and the bibliography discussed in her article. 
10 who freely volunteer together for this truth and to walk according to his will. ${ }^{46}$

Equally clear is the wording of the already quoted CD 3:12-14:

12 But with those who remained steadfast in God's precepts, 13 with those who were left from among them, God established his covenant with Israel forever, revealing 14 to them hidden matters (נסתלות להם) נסתרות) in which all Israel had gone astray. ${ }^{47}$

היאה) No wo woth the beginning of the quote from 1QS מדרש) (מדרש התורה (מדה מתורה האחרון, preserved on 4Q270 7 ii $15^{49}$ and partially on 4Q266 11 $20-21^{50}$ ) use the word midrash, from the same root as doresh. I think we can conclude that "the voice of Teacher" is used within the collection of manuscripts as an authority-conferring strategy for compositions that expand and adapt the Torah to the needs of the group, and that "reveal" what in the Torah has remained "hidden" from all Israel. ${ }^{51}$ And as we are going to see, "the voice of the Teacher" is also used to confer authority to compositions that read the present and the history of the groups in the words of the classical Prophets.

\section{The Teacher as Interpreter of the Prophets}

Within the core "sectarian" compositions, we find many references in which the same divine authority is attributed to the "Law of Moses" and to the "words of the Prophets." The often quoted text from 1QS 8:15 is perhaps not completely clear, since it uses two distinct verbs: גלו ברוח קודש for the Torah, and the Prophets,

${ }^{46}$ DSSSE 1:81.

${ }^{47}$ DSSSE 1:555.

48 Both Harmut Stegemann, "Toward Physical Reconstructions of the Qumran Damascus Document Scrolls," in The Damascus Document: A Centenial of Discovery (ed. J. M. Baumgarten, E. G. Chazon and A. Pinnick; STDJ 34; Leiden: Brill, 2000), 193, and Wacholder, The New Damascus Document, 22 and 109-112, reconstruct this phrase also at the beginning, as the title of the composition.

49 DJD 18:166.

50 DJD 18:76.

51 Shemesh and Werman ("Hidden Things," 421) formulate the same thought this way: "What emerges from this imagery is the sect's conception of revelation of concealed law. This is perceived as taking place via divine inspiration granted to the sect's leaders: under their tutelage the entire membership of the sect engages in the study and interpretation of Torah." 
although in both cases the origin of the authority of the Torah and of the Prophets is the same, since it is God himself who "commands" and who "reveals." But other texts, such as 1QS 1:3, show that both groups of writings have the same authority within the group, precisely because both have the same divine origin: "as he (God) commanded by the hand (ביד) of Moses and by the hand (ביד) of all his servants the Prophets." The same authority is also attributed to other writings. CD 16:1-4 puts the Torah of Moses and the Book of Jubilees on exactly the same level, since in both cases exactly the same verb is used:

1 Therefore, one will impose upon $<$ him $>$ self to return to 2 the law of Moses, for in it all is defined (מדוקדק). And the exact interpretation of the their ages about the blindness 3 of Israel in all these matters, behold, it is defined (מדוקדק) in "The book of the divisions of the periods 4 according to their jubilees and their weeks." ${ }^{52}$

We have seen that the Teacher and the Interpreter (or whoever holds the function of doresh in the group) is able to explain the secret meaning of the Law thanks to revelatory exegesis. We should thus conclude that the same revelatory exegesis is applied in the texts to the books of the Prophets. But concerning these "books of the Prophets" the texts clearly go a step further, and suggest that the Teacher himself is the recipient of direct revelation, which allows him to know "all the mysteries of the words of his servants the Prophets," as it is said in the Pesher Habakkuk (1QpHab 7:4-5). "The voice of the Teacher" not only explains the secret meaning of the words of the prophets, but extends the revelation contained in their words. What was not revealed to the Prophet has been made known to the Teacher, and it is the "Teacher's voice" that guarantees its veracity:

1 And God told Habakkuk to write what was going to happen to $2<$ to $>$ the last generation, but he did not let him know the consummation of the era. 3 And as for what he says (Hab 2:2) "So that /may run/ the one who reads it." 4 Its interpretation concerns the Teacher of Righteousness, to whom God has made known 5 all the mysteries of the words of his servants, the prophets (1QpHab 7:1-5). ${ }^{53}$

Here, the Teacher of Righteousness is apparently the historical Teacher of the past, who, as has been duly noted by many, although he is never called nabi in the Scrolls, is clearly presented as the expected "prophet

\footnotetext{
52 DSSSE 1:565.

53 DSSSE 1:17.
} 
like Moses" in Deut 18:15. ${ }^{54}$ But the function of extending the revelation contained in the words of the Prophets is not restricted to this historical person, but is a function permanently present within the group. This is clear in a text of the same Pesher Habakkuk, which contains a triple interpretation of the same quote, the word בוגדים "traitors," of Hab 1:5:

1 [The interpretation of the word concerns] the traitors with the Man of 2 the Lie, since they do not [believe in the words of] the Teacher of Righteousness from the mouth of $3 \mathrm{God}$; and (it concerns) the traitors [of the] new covenant.] si[n]ce they do not 4 believe in the covenant of God [and dishonoured] his holy na[me]. 5 Likewise: the interpretation of the word [concerns the trai] tors in the last 6 days. They are the violator[s of the coven] ant who will not believe 7 when they hear all that is going [to happen t]o the final generation, from the mouth of 8 the Priest whom God has placed wi[thin the commun]ity to foretell the fulfilment of all 9 the words of his servants, the Prophets, [by] means of whom God has declared 10 all that is going to happen to his people Is[rael.] (1QpHab 2:1-10) ${ }^{55}$

In this text, there is a clear difference between the historical Teacher (the one who opposed the Men of the Lie) and the "traitors" of his days who disregarded his words which came "from the mouth of God," and the Priest in the last days and the traitors who will not believe what they will hear from his mouth. This Priest of the last days will then have the same function the historical Teacher had, that is, to "foretell the fulfilment of all the words of the Prophets."

This text (along with several others) allows us to understand clearly that the group that put together the collection of manuscripts saw itself within the continuous tradition of divine revelation where the writings that would end up as Scripture were growing and taking definite shape, and that therefore they understood themselves to have the right to prolong and develop this revelation. The authority of the Prophets, as the Serek says, came from the inspiration of the divine spirit, and this inspiration continues within the group in what I called many years ago "prophetic exegesis." 56 The Teacher of Righteousness, like the Interpreter, searches the Torah, the Prophets, and all other

\footnotetext{
${ }^{54}$ See the article by George J. Brooke, "Prophecy," in EDSS 2:694-700 and Jassen, Mediating the Divine.

${ }^{55}$ DSSSE 1:13.

${ }^{56}$ Florentino García Martínez, "Escatologización de los Escritos proféticos en Qumrán," EstBib 44 (1986): 101-116.
} 
writings considered authoritative, and in this task he is assisted by the same divine inspiration which is the origin of those writings. It is this inspiration, this divine revelation, which allows him not only to understand the true meaning of those writings, but to invest new writings with the same authority.

What I have called "the voice of the Teacher" is what Adam van der Woude described in his farewell lecture as:

[A]n authoritative body within his circle which, besides Scripture, decides on doctrine and life and which, appealing to inspiration by the Holy Ghost, feels justified in adapting the tradition to the current situation. In that case the norm is not only provided by the prophetic inspiration in the past of which Scripture is the result, but also and not in the last place by the claim of those who feel guided in the present by the Spirit of God. ${ }^{57}$

Although only attested for this period within the collection from Qumran, I do not think that this authority-conferring strategy belongs exclusively to the Qumran group. In the same article, I underlined how this strategy of the pesharim was rooted in the biblical text. And we should not forget that, according to scholars working with the socalled "biblical texts" of the collection, everything points to the conclusion that the situation we find in this collection of manuscripts is not peculiar to the group that brought the collection together, but reflects the general situation before the "great divide." In the words of Eugene Ulrich:

With regard to the biblical scrolls, there is no evidence whatsoever in any scroll of any book that the text was changed due to any interest, belief, practice, or polemic connected with the Qumran community. ${ }^{58}$

${ }^{57}$ His farewell lecture was published both in Dutch and in English. Adam S. van der Woude, Pluriformiteit en uniformiteit: Overwegingen betreffende de tekstoverlevering van het Oude Testament (Kampen: Kok, 1992). The English translation by Anthony Runia was published at the same time: Adam S. van der Woude, "Pluriformity and Uniformity: Reflections on the Transmission of the Text of the Old Testament," in Sacred History and Sacred texts in Early Judaism: A Symposium in Honour of A. S. van der Woude (ed. J. N. Bremmer and F. García Martínez; Contributions to Biblical Exegesis and Theology 5; Kampen: Kok-Pharos, 1992), 151-169; the quote is on pp. $167-68$, italics in the original.

${ }^{58}$ Eugene Ulrich, "The Qumran Biblical Scrolls-The Scriptures of Late Second Temple Judaism," in The Dead Sea Scrolls in Their Historical Context (ed. T. H. Lim et al.; Edinburgh: T\&T Clark, 2000), 67-87, 80. 
This conclusion is shared by George Brooke:

I have proposed in this brief contribution that there is nothing particularly distinctive or sectarian about the pluralism of the biblical texts as discernible in the Qumran caves. This pluralism is known and used in interpretation and to some extent is recognized as interpretation itself. ${ }^{59}$

Thus, although only attested in this period within the collection, I think we can also suggest that this authority-conferring strategy was more general and could have been used by other groups that composed their own writings and attributed to them the same authority of sacred writings. At least, this is certainly the strategy used later on by the writers of the New Testament to confer authority on their own writings.

\section{Conclusion}

This paper has simply re-stated the obvious: that within each group, their own writings are considered authoritative, precisely because they are their own. But in the historical perspective of the forming of the collection, before the "Great Divide" of which Talmon speaks, this simple fact is not without importance. The writers of the core "sectarian" compositions saw themselves participating in the same revelatory process which has given them the sacred books of Moses and of the Prophets, and the many other revealed writings they were reading, interpreting, rewriting, transforming and adapting to their own needs in the period of history they called אחרית הימים.

I may be unduly influenced in my approach by the work I have being doing lately on the relationship between the Scrolls and another collection of writings produced by another Jewish group of approximately the same period, the New Testament. ${ }^{60}$ It is evident that the Christian "Bible" is formed by books recognized as authoritative by the members of the nascent Christian group (the Old Testament, even if also in this case it is difficult to be sure precisely what books were then considered authoritative), and a whole collection (then also of imprecise shape) of new writings of their own (the New Testament)

\footnotetext{
${ }^{59}$ George J. Brooke, "E pluribus unum: Textual Variety and Definitive Interpretation in the Qumran Scrolls," in The Dead Sea Scrolls in Their Historical Context, 107-119, 119.

${ }^{60}$ Florentino García Martínez, ed., Echoes from the Caves: Qumran and the New Testament (STDJ 85; Leiden: Brill, 2009).
} 
considered equally authoritative. ${ }^{61}$ If we want to talk of the "Qumran Bible," we should thus not only go beyond the "canonical divide" but also beyond the "sectarian divide," and we should consider each composition of the whole collection on its own; and on the basis of the partial and accidental evidence which has reached us, we should decide in each case the authority each single book may have had for the group that put the collection together. From this perspective, "the voice of the Teacher" should be understood to be as strong a claim as "the voice of Moses" or the revelation through the Prophets.

${ }^{61}$ See Julio Trebolle Barrera, La Biblia Judía y la Biblica Cristiana: Introducción a la historia de la Biblia (Estructura y Procesos: Serie Religión; Madrid: Trotta, 1993). 